Journal of Economics and Behavioral Studies

Vol. 3, No. 5, pp. 287-295, Nov 2011 (ISSN: 2220-6140)

\title{
Significance of Lean, Agile and Leagile Decoupling Point in Supply Chain Management
}

\author{
Faiza Amir \\ SZABIST Islamabad Campus Pakistan \\ faiza@szabist-isb.edu.pk
}

\begin{abstract}
A supply chain is a system, consisting of material suppliers, production facilities, distribution services and customers. These are all linked together through the downstream feed forward flow of materials and the upstream feedback flow of information. Several organizations have adopted the concept of "Lean" to improve the performance and position in the market place and. The "Agile" manufacturing has been recently emerged as a customer demand driven option. It defines as using market knowledge and virtual corporation to exploit profitable opportunities in a volatile marketplace, leanness stands for developing a value stream to eliminate all waste, including time and to ensure a level schedule. Leagile is one suitable way to exploit the both approaches, lean and agile. It requires the selection and setting up of a material flow decoupling point. The positioning of the decoupling point, therefore, depends upon the longest lead-time and at the same time customer is prepared to tolerate this time lag and the point at which variability in product demand dominates. Downstream from the decoupling point all products are pulled by the customer demand, that is why that part of supply chain is market driven. Upstream from the decoupling point the supply chain is essentially forecast driven. This review paper will explore the approaches of lean, agile and leagile decoupling point to suggest the most suitable supply chain practices, processes and procedures. Several factors are needed for lean and agile practices' success; not only is it necessary to implement most of the technical tools but an organization's culture needs transforming too.
\end{abstract}

Keywords: Lean, Agile, Decoupling point, Upstream, Downstream, Lead time.

\section{Introduction}

A supply chain is a system consisting of material suppliers, production facilities, distribution services and customers who are all linked together through the downstream feed-forward flow of materials (deliveries) and the upstream feedback flow of information (orders). In an established supply chain, each member is responsible for his own inventory control system and production or distribution ordering procedures. Another basic attribute of supply chain and production/inventory control problem is that all members in a traditional supply chain e.g. retailers, distributors, manufacturers and raw material supplier must solve, "just how much to order, the production system to produce and the suppliers to supply, so as to facilitate a supply chain echelon to satisfy its customer's demands".

The emerging trend in current business markets is that it's supply chains that compete, not companies and the deciding factor for the success and failure of any supply chain is determined by the customers. Providing the right product, at the right price, at the right time to the customer is the key for the success and survival in this era of cutthroat competition. Supply chain works for improving integration between supply and demand, to provide satisfaction to customer. Improvement in supply chain helps reducing uncertainty in the system and bullwhip effect. Many organizations have adopted the concept of "Lean" to improve the performance and position in the market place and recently the agile manufacturing has been emerged as an alternative to leanness (Womack \& Jones, 1994; Richards 1996). Now what are these two concepts lean and agile, according to the Naylor et al. (1999) agility defines as using market knowledge and virtual corporation to exploit profitable opportunities in a volatile marketplace and leanness stands for developing a value stream to eliminate all waste, including time, and to ensure a level schedule.

It may not be advisable to adopt a single approach to understand this dynamic business world and there is not any "one fit for all" formula. If lean means waste reduction and agile means optimization of the processes, sometime organization wants them to be at the same time. There has been recently some significant debate 
about the advantages and disadvantages of lean and agile approaches in supply chain management, some suggest these are mutually exclusive, other says that these approaches can complement each other (Towill \& Christopher, 2002). The underline focus of leanness is cost minimization and value addition in specific product, which can be achieved through the concept of TQM (total quality management), continues improvement and quality assurance at every level and stage of supply chain. On the other hand, agility stands for a system of doing business in which entrepreneurs introduce the new product with the objective of sustainability in the dynamic competitive markets.

A new emerging trend is hybrid approach that leanness and agility can be combined with strategic use of decoupling point, to optimize the benefit of both concepts by adopting leagile supply chain and getting the best of the both worlds (Towill et al., 2000). This combined approach is known as 'Leagility' and, as a consequence, the supply chain can thereby adopt a lean manufacturing approach upstream, enabling a level schedule and opening up an opportunity to drive down costs upstream while simultaneously still ensuring that downstream of the de-coupling point there is an agile response capable of delivering to an unpredictable demand of marketplace.

Leagile is one of suitable ways to exploit both the approaches, lean and agile. It requires the selection and setting up of a material flow decoupling point. Upstream of this decoupling point, the processes are designed to be lean (Level scheduling) and downstream, processes are designed to be agile (Responsive). This review paper will explore the approaches of lean, agile and leagile decoupling point to suggest the most suitable supply chain practices, processes, procedures and their practical implications in the modern, dynamic, global, competitive business world.

Objective: The objective of this paper is to in-depth review of the concepts of lean, agile and the emerging approach of leagile decoupling point paradigm. For the stated purpose, a detailed literature review has been conducted in this regard and different dimensions of the lean and agile supply chain have been discussed at length. The main purpose of the research is to investigate the application and significance of the decoupling point which is a relatively new concept in the dynamics of supply chain management. Business wants to achieve the best possible utilization of the resources while maintaining optimum level of operation and providing maximum level of satisfaction to the customers for survival in this competitive market place. This review paper will explore the approach of leagile decoupling point to suggest the most suitable supply chain practices, processes and procedures.

\section{Literature Review}

Manufacturing progress in the 80s (TQM, Lean management and JIT) helped many organisations improve their manufacturing efficiency and reduce costs. However, competition in worldwide markets, demanding customers, the need to deliver value, revolutionary advancements in technology are some of the aspects that have led organisations world-wide to re-evaluate their operations. The need to be flexible and efficient while minimising costs has resulted in the focus on all operations that impact on the flow and transformation of manufactured goods. Management understands that running of material and service inputs from the supplier base and the distribution of finished goods offer new challenges and opportunities. The primary aim is to efficiently deliver higher value products with lesser input, hence in cost effective manner. The magic word is "Lean".

Leanness: A lean supply chain process has been rationalized to reduce and eliminate waste or non-value added activities to the total supply chain flow and to the products moving within the supply chain, it is destined to reduce surplus inventory in the supply chain. Compressing cycle time and increasing inventory swiftness are the preferred results for lean supply chain management. The most common sources of wastes are; over supply, transportation, inventory, waiting, movement, defective service or product and over processing.

The sources of lean thinking can be found on the shop floors of Japanese manufacturers and, in particular, innovations at Toyota Motor Corporation (Shingo, 1981; Monden, 1983). These innovations, resulting from a shortage of resources and strong domestic competition in the Japanese market for automobiles, included the 
just-in-time (JIT) production system, which is in fact the spirit of lean and agile practices. Another important aspect of Japanese production system is the respect for their employees and high levels of employee problem solving. According to Monden (1983) the lean operations management design approach focused on the elimination of waste and excess from the planned product flows at Toyota (the Toyota "seven wastes") and represented an alternative model to that of capital intensive mass production, with its large batch sizes, dedicated assets and the hidden wastes.

Major part of the early work process at Toyota was under taken during the leadership of Taiichi Ohno in auto engine manufacturing in the 1950s, then to vehicle assembly during 1960s, and finally it was applied to the wider supply chain in period of 1970s. At the latter stage of application, the supplier manuals were produced and the secrete tips of this lean approach were shared with companies outside Toyota for the first time. These manuals were written in Japanese, and it took almost another ten years before the first literature translated in English language was available (e.g. Shingo, 1981; Schonberger, 1982; Hall, 1983; Sandras, 1989). Still, the interest taken in lean by the western manufacturers was limited until the performance gaps between Toyota and other carmakers were highlighted by the book "The Machine that Changed the World", which also introduced the term "lean production" or "lean manufacturing" (Womack et al., 1990).

The purpose of a lean supply chain is to meet the 8R's which are right materials, right quantity, right time, right place, right source, right service, right price and right quality, if these are taken in consideration appropriately then we can reap the benefits of the leanness in best possible manner. The components of the "Lean Supply Chain" are lean suppliers, lean procurement, lean manufacturing, lean warehousing, lean logistics and lean customers. When the requirements and constraints of the marketplace are understood, only then an enterprise can try to develop a strategy that will meet the needs of both the supply chain and the end customer. The supply chain performance enhancement programs strive to match supply to demand and consequently driving down costs concurrently with improving customer satisfaction. This requires perpetually reducing uncertainty within the supply chain, as much as practicable to facilitate a more predictable upstream demand (Mason- Jones et al., 1999).

At times, it is difficult to remove uncertainty from the supply chain because of the nature of the products involved. For instance, if a commodity is highly fashionable and its innate nature of high value, its demand will be unpredictable. Explicit supply chains are usually deal with the circumstances where they have to tolerate uncertainty. They need to develop an effective strategy that facilitates them to match supply and demand. Due to these reasons significant interest has been shown in recent years in the idea of lean manufacturing (Womack, Jones \& Roos, 1990), and the wider concepts of the 'lean enterprise' (Womack, \& Jones, 1996). In essence, the lean approach emphasize on the elimination of waste. The increased focus and interest in lean manufacturing can be traced to the Toyota Production Systems (TPS) with it's emphasize on the reduction and elimination of waste (Ohno, 1988).

Agility: One of the biggest challenges to organizations today, is the need to respond to ever-increasing levels of volatility in demand. When the demand is unstable and the customer requirement for variety is high, a much higher level of agility is required. The concept of agility is defined as a business wide capability that integrates organizational structures, information systems, logistics processes and specially, mindsets. An important characteristic of an agile organization is flexibility and adaptability. The origins of agility as a business concept relates to flexible manufacturing systems (FMS).To meet this challenge of volatility of demand; the organization needs to focus its efforts upon achieving greater agility such that it can respond in shorter periods both in terms of volume change and in terms of variety change. The concept of agility should not be considered same as leanness.

In the beginning it was a popular belief that the way to manufacturing flexibility and adaptability was through mechanization to smooth the progress of swift changeovers (i.e. reduced set-up times) and that is why enable a greater responsiveness to changes in product mix production quantity. Later this idea of manufacturing flexibility was extended into the wider business context (Nagel \& Dove, 1991), and the concept of agility as an organizational orientation was born. It is becoming increasingly evident that competitive advantage derives from the combined capabilities of the network of linked organizations, are called 'the supply chain' in the present business world. This concept of the business model is a fundamental shift from the traditionally held 
view of a business model based upon a single company. With the technological advancements and market competition, it is becoming obvious that markets are increasingly volatile and that is why less predictable. Therefore, the requirement for an extra agile response has grown. Integrating these two approaches directs us to the conclusion that an agile supply chain is a pre requisite for success in present volatile markets.

Agile supply chains are, that utilize strategies aimed at being responsive and flexible to customer needs, while the risks of supply shortages or disruptions are hedged by pooling inventory or other capacity resources. These supply chains essentially have strategies in place that combine the strengths of "hedged" and "responsive" supply chains. They are agile because they have the capability to be responsive to the shifting diverse and unpredictable demands of customers on the front end, while minimizing the back-end risks of supply disruptions.

Leagile: Leagile is the combination of the lean and agile paradigms within a complete supply chain strategy by positioning the decoupling point at a particular desired point, so that it will best suit the need for responding to an unpredictable demand of the markets downstream and at the same time making possible to facilitate, level scheduling upstream from the marketplace (Naylor et al., 1997). The innovative use of information technology in the field of supply chain, to share information data between buyers and suppliers is, in fact creating a virtual supply chain. Virtual supply chains are information centered rather than inventory focused. The creative approach of electronic data interchange (EDI) and the Internet have enabled partners in the supply chain to act upon jointly on the same information data. In traditional supply chain inventory management, orders are the only information firms' exchange. But information technology now allows firms to share demand and inventory data quickly and inexpensively. Using the internet to develop agile supply chains with information sharing, coordination and postponement has enabled companies such as Xilinx and Adaptec to compete successfully in their market places. The Challenges are great, but so are the opportunities. The internet has enabled companies to tap into bigger supply base to ensure reliable supply of the products so as to be responsive.

Discussion \& Analysis: According to Lee (2002) demand and supply uncertainties can be used as a framework to devise the right supply chain strategy. Innovative products with unpredictable demand and an evolving supply process face major challenges. When product demand is unpredictable, pursuing a responsive supply chain strategy is more appropriate than a cost effective strategy. While agility can make the supply chain very responsive at the same time leagile is the most suitable strategy for the purpose.

Because of shorter and shorter product life cycles, the pressure for dynamically adjusting and adapting a company's supply chain strategy is increasing. In early 1995, A Compaq manager lamented in the trade press that HP was light years ahead of competition, in its ability to deliver products quickly and at a low cost (Cochaon \& Fisher, 2000). Many success stories have resulted from collaborative efforts of manufacturing, engineering, distribution and marketing organizations. In the following diagram, Hines et al. (2004) have very appropriately elaborated the concept of leagile, as showing the importance of waste elimination and customer satisfaction at the equilibrium for supply chain players. It is becoming more and more desired for upstream and downstream supply chain members as vital for sustainability in the dynamic and competition driven business world.

\section{Figure 1}

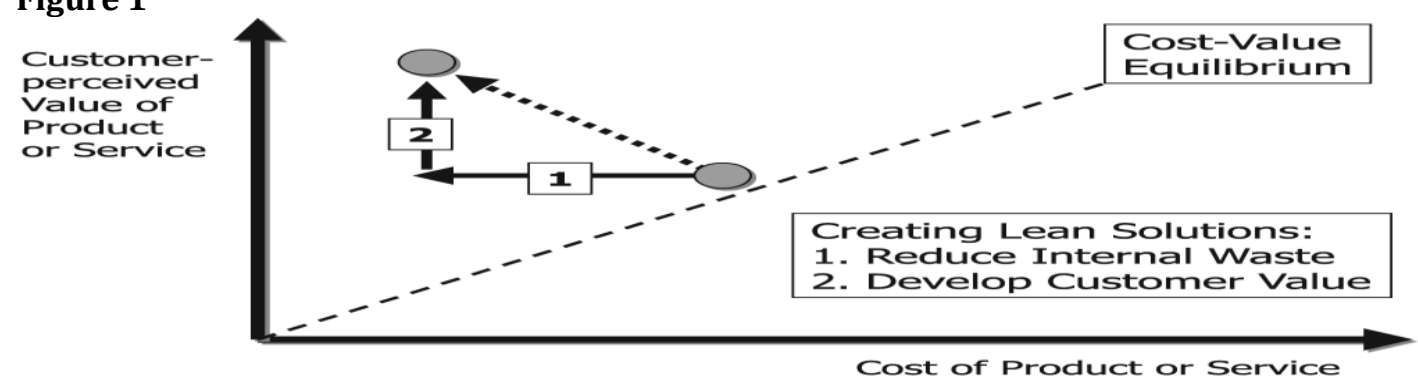

Source: Peter Hines et al. (2004), learning to evolve: A review of contemporary lean thinking. 
Leanness and agility are the two approaches, which must be integrated at all levels in the organizations. The conceptual framework in this regard developed by Hines et al. (2004) exhibits that there are five principles involved in lean thinking, which are lean procurement, lean production, lean operation, quality control and lean distribution. These elements are essential for total quality management (TQM) approach and directly related to continues improvement philosophy. The application of TQM at all echelon is the requirement of continues improvement for leanness. For better inventory management practices, new emerging concept is JIT (Just in time) inventory system, which can only work with zero fat (waste). It is only possible through the lean practices of waste minimization and ultimately application of TQM practices.

Figure 2

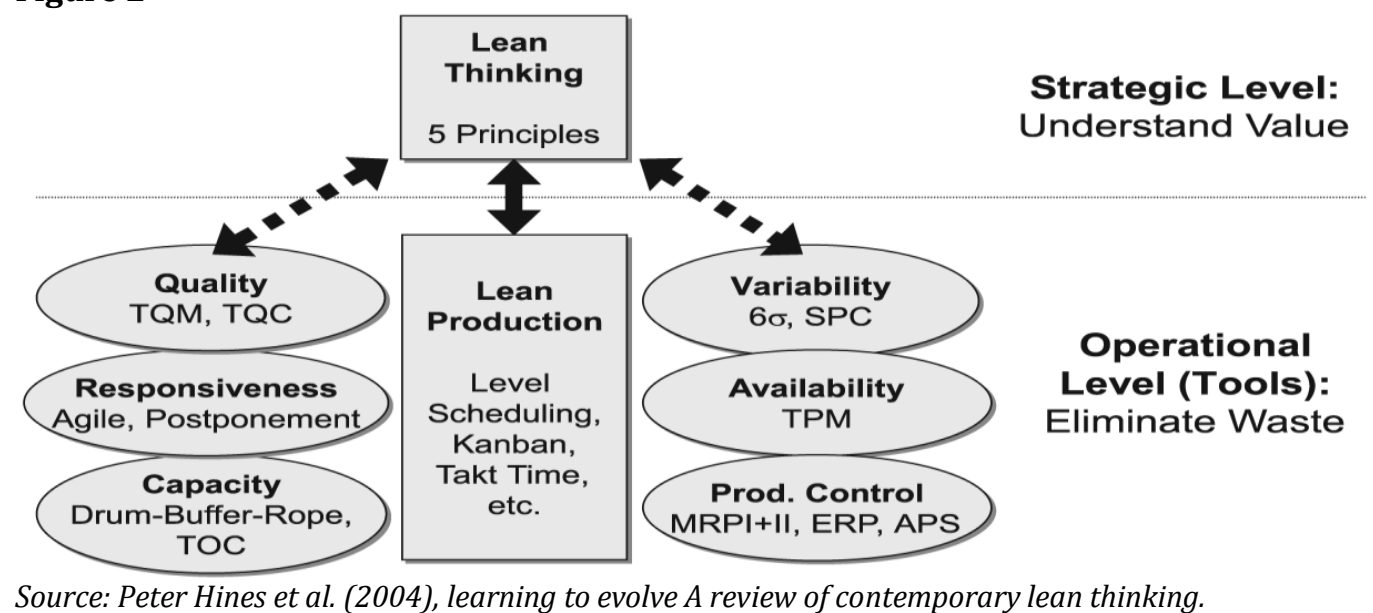

According to Hines et al. (2004) at strategic level at one side five principles of lean thinking are important for success, then on other side at operational level at action stage along with leanness, TQM, 6 $\sigma$, ERP, the responsiveness and agility is the key for success. As for agility, a precise, conscious and consistent effort is required at the level of downstream supply chain players to be able to meet the volatile demand of the customer and provide optimum service level. It is only possible through well-organized and integrated effort from the whole supply chain players at different echelons. All these can be possible through leagile philosophy by achieving and sustaining the most appropriate decoupling point in the supply chain management.

Figure 3

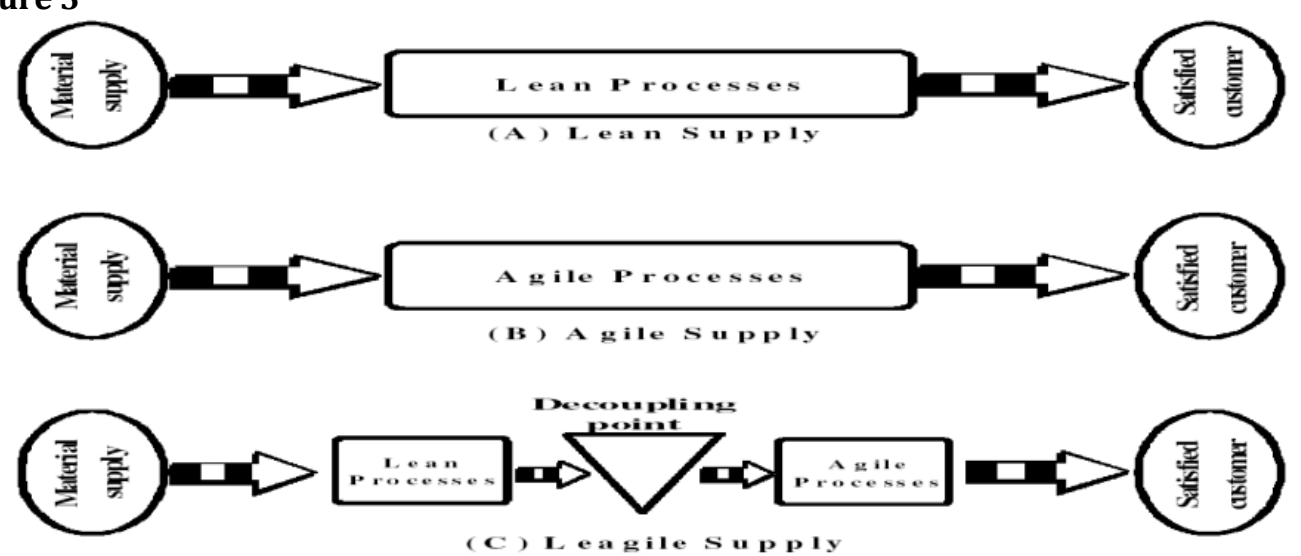

Source: Towill et al. (2000) Lean, agile or leagile? Matching your supply chain to the marketplace

The decoupling point is the point in the material flow streams to which the customer's order penetrates. At this specific point, the order driven and the forecast driven actions and strategies connect. As a rule, the decoupling point coincides with an important stock point subject to some addition or deletion, in control 
terms a main stock point \pm from which the customer has to be supplied (Hoekstra \& Romme, 1992). The decoupling point positioning is greatly relied upon the longest lead-time and customer is prepared to endure it at the same time the variability in product demand dominates. Downstream from the decoupling point all products are pulled and influenced by the customer, that's why we called this feature as market driven trait of decoupling point in supply chain. Upstream from the decoupling point the supply chain is primarily forecast driven, which depends greatly upon the forecasting techniques used by the respective players in the supply chain. In nutshell, it all greatly relies upon the close and efficient integration and the coordination of the upstream and downstream activities of all stakeholders and the supply chain players.

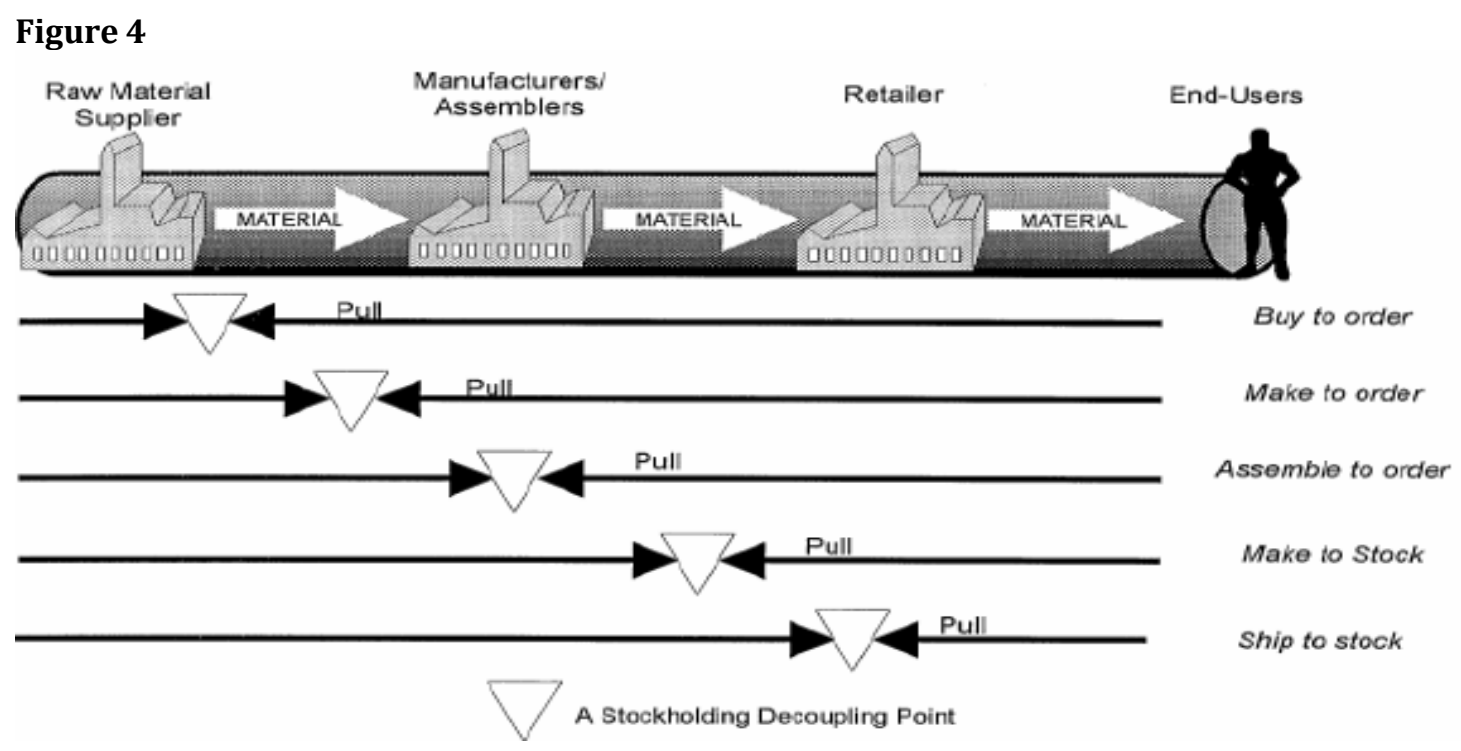

In this contest, the concept is to hold inventory in some basic or prepackage form and only complete the final packing or completion when the specific customer requirement is known, e.g. the customized PC (Christopher and Towill, 2000). The concept of "postponement" is now increasingly widely employed by organizations in different industries (Van Hoek, 1998). As shown in Figure by utilizing the idea of postponement, companies may utilize lean methods up to the de-coupling point and agile methods beyond it. As we moves on the supply chain the decoupling point is pushing towards come end customer and it all becomes demand driven activity. Companies such as Hewlett-Packard have successfully employed such strategies to enable products to be localized much closer in time to actual demand (Feitzinger \& Lee, 1997). However, as Pagh and Cooper (1998) have pointed out, satisfying customer demand may require particular combinations of postponed manufacture and postponed logistics.

A parallel concept to the material de-coupling point described above is that of the information de-coupling point (Jones \& Towill, 1999). This represents the furthest point upstream to which information on actual demand flows, i.e. this information is first hand and accurate at the same time it has not been distorted by inventory policies such as re-order points and re-order quantities. The ability to base replenishment decisions on real demand clearly contributes to supply chain agility (Christopher \& Towill, 2001). According to Benjaffar et al (2005), a production and inventory system can be treated as independent units when they are decoupled through large stock holding at the manufacturing facility or at subsequent stages of the supply chain. It may also be justified to do this when the inventory and production system belongs to different entities or when transportation lead-time is much bigger than the manufacturing lead-time.

Recommendation: The dramatic performance improvements available by following lean, low waste principles are well established in high volume, relatively low variety situations. Many companies desire to achieve identical, or better, levels of performance and that is why companies are eager to adopt lean practices in their supply chain. However, the formula of lean practices is applicable openly only to a small section of producers. It is very much important that most organizations must carefully identify and evaluate that which 
lean practices they can implement and use on immediate basis, and which need to be adapted to meet their special circumstances.

It is becoming increasingly apparent that competitive advantage derives from the combined capabilities of the network of linked organizations that today we call "the supply chain". It is a basic modification in the traditional concept of a business framework based upon a single organization. It has also become evident that markets today are increasingly unstable and less predictable. Therefore, the need for a more agile response has grown during the supply chain management practices among businesses. According to Hallgren and Olhager (2009) the result indicates that the lean and agile manufacturing differs in terms of drivers and outcomes. The choice of a waste elimination and cost leadership strategy fully reconciles the impact of the aggressive strength of industry as a driver of lean manufacturing, whereas, agile manufacturing is directly affected by both internal and external drivers i.e. a differentiation strategy, as well as the competitive intensity of industry.

Agile manufacturing is mostly negatively connected with a cost-leadership strategy, stressing the difference between lean and agile manufacturing. The major differences in performance outcomes are related to cost reduction, flexibility and adaptability to customer demand. The lean manufacturing has a significant impact on cost performance, whereas agile manufacturing has not the same impact, and that agile manufacturing has a stronger relationship with volume as well as product mix flexibility than does lean manufacturing. Finally as an integral part, organizations should incorporate the technological advancements in communication channels and flow of supply chain for cost reduction. In addition, through information technology now firms can share demand and inventory data quickly and inexpensively. Using the internet to develop agile supply chains with information sharing and coordination, efficiency can be enhanced and profitability increased.

\section{Conclusion}

Summing up the discussion, many diverse factors are needed for lean and agile practices success; not only is it necessary to implement most of the technical tools but an organization's culture needs transforming too. Moreover, the modifications need to be implemented throughout an organization's value chain. Leagile has major strategic significance importance and edge, though its implementation procedure, HRM implications, general approach to the supplier base coupled with the overall universal conviction of viewing leagile as a set of approaches rather than embracing it as a philosophy.

The decoupling point is the point in the material flow streams to which the customer's order penetrates. It is here where order driven and the forecast driven activities meet. As a rule, the decoupling point coincides with an important stock point \pm in control terms a main stock point \pm from which the customer has to be supplied (Hoekstra \& Romme, 1992). The positioning of the decoupling point therefore depends upon the longest leadtime and making customer ready to endure the waiting period, at the same time at this point variability in product demand dominates in the market place. Downstream from the decoupling point all produced commodities are pulled by the customer, that is why, they are market driven. Upstream from the decoupling point the supply chain is usually forecast driven.

Future Research: As the applicability and the effectiveness of the concept got established given the examples of the first world industries, a future research can be done on the same level for the second and third world's economies by comparing with the results and implications of the concept for the first world through an empirical study and conceptual model.

Acknowledgment: All praises for Allah (SWT) who is the most beneficent and most merciful, has granted courage and ability to creatures for undertaking the tasks. "Believers! If you fear, Allah He will grant you a criterion and will cleanse you of your sins and forgive you. Allah is Lord of abounding bounty" (Surat Al-Anfal $08 \mathrm{Al}$-Quran). Special thanks to Dr Taraq Waheed for carrying out professional editing of the research paper for the author. 


\section{References}

Christopher, M., Towill, D. R. (2000). Supply chain migration from lean and functional to agile and customized. International Journal of Supply Chain Management, 5(4), 206-13.

Christopher, M. (2000). The Agi le Supply Chain: Competing in Volatile Markets. Ind Mark Man, 29(1), 37-44.

Benjaffar, S., Cooper, W. L. \& Kim, J. S. (2005). On the benefits of pooling in production inventory system, Management Science, 51(4), 548-565.

Christopher, M. \& Towill, D. (2001). An integrated model for the design of agile supply chains. International Journal of Physical Distribution \& Logistics Management, 31(4), 235-246.

Cachon, P. G. \& Fisher, M. (2000). Supply Chain Inventory Management and the Value of Shared Information, Management Sciences Informs, 46(8), 1032-1048.

Denis, T. \& Martin, C. (2002). The Supply Chain Strategy Conundrum: To be Lean Or Agile or To be Lean And Agile? International Journal of Logistics: Research and Applications, 5(3).

Feitzinger, E. \& Lee, H. L. (1997). Mass customisation at Hewlett Packard - the power of postponement. Harvard Business Review, 116-21.

Hall, R. (1983). Zero Inventories. Dow Jones-Irwin, Homewood, IL.

Hau, L. L. (2002). Aligning Supply Chain Strategies with Product Uncertanities. California Management Review, University of California CMR, 44(3).

Hoekstra, S. \& Romme, J. (1992). Integral Logistics Strictures: Developing Customer-orientated Goods Flow, Simon and Schuster: New York.

Mason-Jones, R. \& Towill, D. (1999). Using the Information Decoupling Point to Improve Supply Chain Performance. International Journal of Logistics Management, 10(2), 13-26.

Mason-Jones, R., Naylor, B. \& Towill D. R. (1999). Lean, Agile, or Leagile-Matching Your Supply chain to the Marketplace. Proc. 15th Int. Conf. Prod. Res., Limerick, 593-596.

Mason-Jones, R., Naylor, J. B. \& Towill, D. (2000). Engineering the Leagile Supply Chain, to be published, Int. Jnl. Agile Man. Systems.

Christopher, M. \& Towill, D. (2001). An integrated model for the design of agile supply chains. International Journal of Physical Distribution \& Logistics Management, 31(4), 235-246.

Hallgren, M. \& Olhager, J. (2009). Lean and agile manufacturing: External and interval drivers and performance outcomes. International Journal of Operations \& Production Management, 29(10), 976999.

Monden, Y. (1983). The Toyota Production System. Productivity Press, Portland.

Nagel, R. \& Dove, R. (1991). 21st Century Manufacturing Enterprise Strategy. Incocca Institute, Leigh University.

Naylor, J. B., Naim, M. M. \& Berry, D. (1999). Leagility: integrating the lean and agile manufacturing paradigm in the total supply chain. Engineering Costs and Production Economics, 62, 107-118.

Ohno, T. (1998). The Toyota Production System; Beyond Large Scale Production. Portland, Oregon: Productivity Press.

Pagh, J. D. \& Cooper, M. L. (1998). Supply chain postponement and speculation strategy: how to choose the right strategy. Journal of Business Logistics, 19(2), 13-33.

Hines, P., Holweg, M. \& Rich, N. (2004). Learning to evolve: A review of contemporary lean thinking. International Journal of Operations \& Production Management, 24(10), 994-1011.

Rachel, M. J., Ben, N. \& Denis R. T. (2000). Lean, agile or leagile? Matching your supply chain to the marketplace. International Journal of Production Research, 38(17), 4061-4070.

Richards, C. W. (1996). Agile manufacturing: beyond lean?. Production and Inventory Management Journal, 2, 60- 64 .

Bhasin, S. \& Burcher, P. (2006). Lean viewed as a philosophy. Journal of Manufacturing Technology Management, 17(1), 56-72.

Sandras, W. A. (1989). Just-in-Time: Making it Happen. Unleashing the Power of Continuous Improvement, John Wiley \& Sons, New York, NY.

Schonberger, R. J. (1982). Japanese Manufacturing Techniques. The Free Press, New York, NY.

Shingo, S. (1981). Study of the Toyota Production Systems. Japan Management Association, Tokyo.

Towill, D. R., Childerhouse, P. \& Disney, S. M. (2000). Speeding Up the Progress Curve Towards Effective Supply Chain Management. International Journal of Supply Chain Management, 5(43), 122-130. 
Van, H. R. (1998). Reconfiguring the supply chain to implement postponed manufacturing. International Journal of Logistics Management, 9(1).

Womack, J. P. \& Jones, D. T. (1994). From lean production to the lean enterprise. Harvard Business Review, March-April, 93-03.

Womack, J., Jones D. \& Roos, D. (1990). The Machine that Changed the World. New York, Macmillan.

Womack, J. P. \& Jones, D. T. (1996). Lean Thinking. Simon and Schuster, NY. 